\title{
29. STRUCTURAL SYNTHESIS: CORRELATION OF STRUCTURAL FABRICS, VELOCITY ANISOTROPY, AND MAGNETIC SUSCEPTIBILITY DATA ${ }^{1}$
}

\author{
Timothy Byrne, ${ }^{2}$ Warner Brückmann, ${ }^{3}$ William Owens, ${ }^{4}$ Siegfried Lallemant,${ }^{5}$ and Alex Maltman ${ }^{6}$
}

\begin{abstract}
Structural, physical property, and magnetic data from Ocean Drilling Program Site 808 in the Nankai Trough, Japan, indicate that both sediment loading and plate convergence have driven dewatering and consolidation in this region. Evidence for this interpretation is provided by a migrated seismic reflection profile, computed tomography of core-scale structures, magnetic susceptibility and $P$-wave velocity data, and experimental studies of Site 808 samples. These data also show that the strain (including volume change) resulting from plate convergence is partitioned into both penetrative deformation structures as well as more discrete, core-scale structures with finite displacements. These core-scale structures range from relatively subtle, kink-like deflections of the primary phyllosilicate fabric to sharp discontinuities with probable displacements much greater than the dimensions of the core barrel. Although all of the structures acted at least in part as dewatering conduits, evidence of concentrated fluid flow in this region of the prism is limited to a narrow interval almost $150 \mathrm{~m}$ above the décollement (located at between 946 and $965 \mathrm{mbsf}$ ). This interval correlates with the middle of a hemipelagic sequence above the décollement that appears to have thinned, apparently through dewatering, relative to a more seaward section. Thinning and dewatering appear to have been induced by deposition of a more clastic sedimentary sequence (the outer marginal trench-wedge sediments) that grades upward into a coarse-grained trench-fill sequence. Importantly, the hemipelagic sequence below the décollement appears to have thinned very little, suggesting that these sediments are underconsolidated and overpressured. This interpretation is consistent with porosity measurements from below the décollement. Microscopic and submicroscopic studies of sediments from within the décollement record a cyclic deformation sequence of displacement-brecciation-porosity collapse and compaction that may also reflect deformation of an overpressured sequence. Finally, the structural, physical property, and magnetic data also yield kinematic and geometric results consistent with the present convergent vector between the Philippine Sea Plate and Eurasia. These data indicate a shortening direction that trends between $308^{\circ}$ and $315^{\circ}$, consistent with plate convergent vectors that trend between $310^{\circ}$ and $314^{\circ}$.
\end{abstract}

\section{INTRODUCTION}

Recent studies of the processes occurring at convergent plate boundaries suggest that there is an important but poorly defined interplay between the expulsion of dewatering fluids and the formation of tectonic structures. Tectonic stresses almost certainly accentuate dewatering and lithification through such processes as "tectonic dewatering" (Moore et al., 1986) and "shear dewatering" (Bray and Karig, 1985). For example, in the Barbados accretionary wedge concentrated fluid flow and dewatering correspond directly with zones of tectonically induced faulting and scaly fabric development (Mascle, Moore, et al., 1988). Similarly, the common occurrence of veins, clastic dikes, and mud diapirs in many modern and ancient accretionary complexes indicate substantial fluid flow during accretion (Fisher and Byrne, 1987; Taira et al., 1988; Brown and Westbrook, 1988).

The detailed relation between the state of stress, deformation, and dewatering, however, has remained elusive. This is due in part to the inherit difficulties of obtaining samples in situ and in part to our ignorance of how permeability, diagenetic fronts, and structural fabrics evolve during accretion. In this study we present a summary of structural, physical property, and magnetic data from Ocean Drilling Program (ODP) Site 808 in the toe region of the Nankai accretionary

\footnotetext{
${ }^{1}$ Hill, I.A., Taira, A., Firth, J.V., et al., 1993. Proc. ODP, Sci. Results, 131: College Station, TX (Ocean Drilling Program).

${ }^{2}$ Department of Geology and Geophysics, University of Connecticut, Storrs, CT 06269, U.S.A

${ }^{3}$ GEOMAR - Center for Marine Geoscience Research, Wischhofstr. 1-3, Geb, 4. D-2300 Kiel, Federal Republic of Germany,

${ }^{4}$ School of Earth Sciences, University of Birmingham, P.O. Box 363, Birmingham B15 2TT, United Kingdom.

${ }_{5}^{5}$ Laboratoire de Géologie-Ecole Normale Supérieure, 24 Rue Lhomond, 75231 Paris, Cedex 05, France.

${ }^{6}$ Institute of Earth Studies, The University College of Wales, Aberystwyth, SY23 3DB, United Kingdom.
}

prism of southwest Japan (Fig. 1). These data provide new insights into mechanisms of dewatering and how these mechanisms are related to the plate convergent stresses. Hole $808 \mathrm{C}$ was particularly successful because it penetrated the entire toe of the Nankai accretionary prism, including the frontal thrust, the basal décollement, the underthrust sediments, and the oceanic crust. Moreover, relatively good core recovery allowed structural, physical property, geochemical, and petrologic data to be collected almost continuously. Over $70 \%$ of the 3000 measurements made by the structural geologists were also reoriented to geographic coordinates with paleomagnetic data. Data from Site 808 , therefore, probably provide the most complete structural data set in the history of the Ocean Drilling Program.

In the following paragraphs we first present observations that indicate penetrative deformation of the Nankai sediments. These observations include compressional $(P)$-wave and magnetic susceptibility anisotropy data and an interpretation of a seismic reflection profile (Moore et al., 1990; Taira, Hill, Firth, et al., 1991). The penetrative structures are considered to have formed relatively early in the deformation history, based on observations in the cores and in the seismic reflection profile. We then summarize the geometry, kinematics, and microscopic to core-scale character of the structures present at Site 808. In particular, we emphasize evidence for tectonic consolidation of the accreting sediments and the consistency in kinematics between these structures and the present plate convergent vector. In total, the data indicate three tectono-hydrologic regimes within the toe region of the Nankai accretionary prism: above the décollement, the décollement, and below the décollement. The significance of these different regimes is discussed in the final section of the paper.

\section{EVIDENCE FOR PENETRATIVE DEFORMATION}

Evidence for penetrative deformation comes from three types of data: a line drawing of a migrated seismic reflection profile (from 


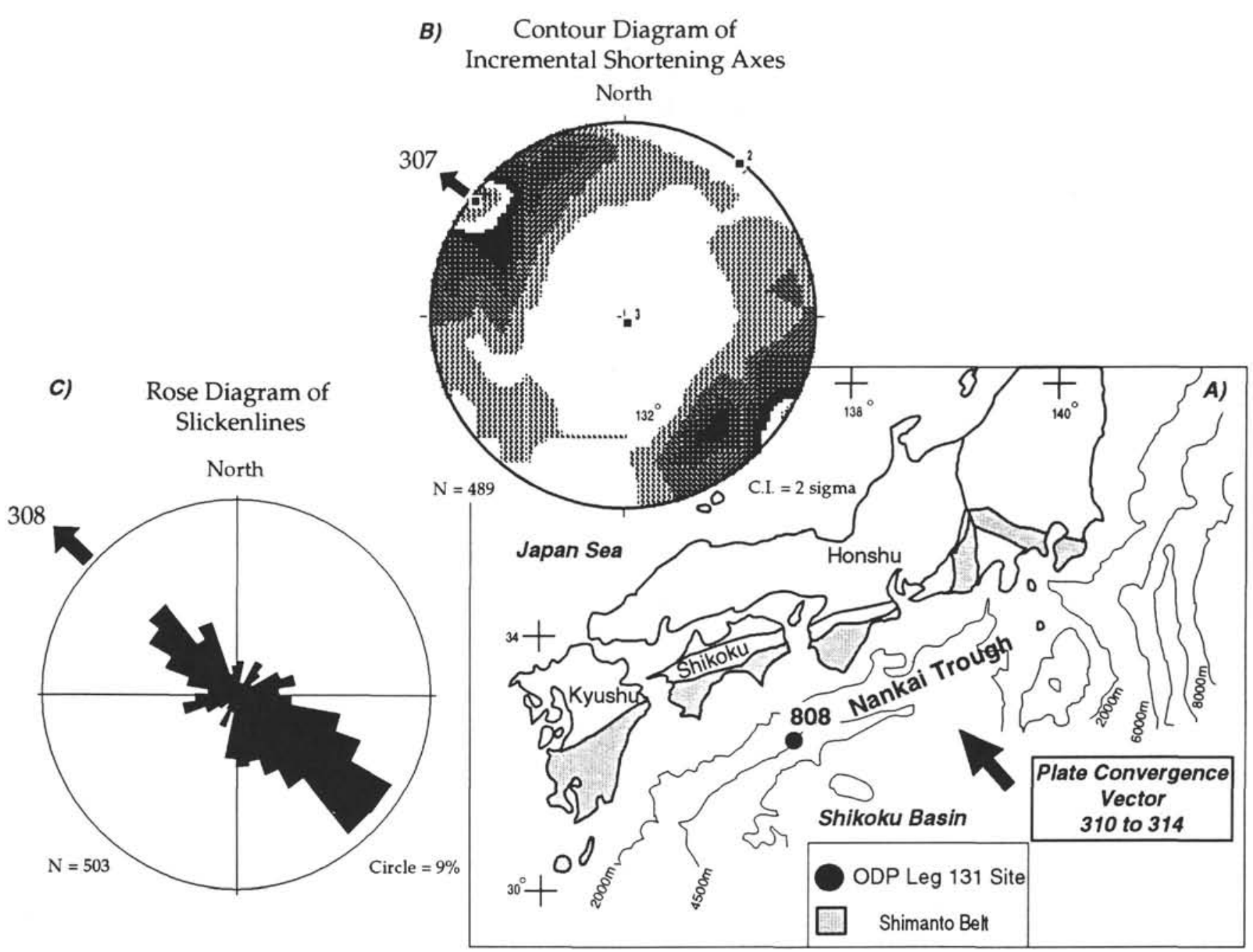

Figure 1. Location map of Site 808 (A) and structural data (B and C) from this area. Location map also includes the plate convergence vector for the Philippine Sea and Eurasia plates. Stereonet (B) is a contour diagram (at 2-sigma intervals) showing the distribution of $P$ axes (see text for technique) from Site 808. Rose histogram (C) shows the orientation of slickenlines associated with the faults used to construct (B).

Taira, Hill, Firth, et al., 1991; see also Moore et al., 1990), anisotropy of magnetic susceptibility (Owens, this volume), and $P$-wave velocity anisotropy data (Byrne et al., this volume; Brückmann et al., this volume). The seismic reflection profile and compressional wave velocity data were collected during pre-cruise investigations and during Leg 131, respectively, and detailed discussions of the techniques and results are presented in Taira, Hill, Firth, et al. (1991; see also Moore et al., 1990). More recently, we have oriented the velocity data using magnetic remanence directions (Byrne et al., this volume; Brückmann et al., this volume) and a summary of these results are presented below.

\section{Seismic Reflection Data}

In order to present our interpretations of the seismic reflection profile as clearly as possible, Figure 2 provides a line drawing of the major features we have recognized. Many of these features are also discussed by Moore et al. (1990). For example, their diagrams show clearly the décollement and the geometry of the folds and faults in the accreted material above the décollement. Moore et al. (1990) also noted that the décollement is marked by a nearly continuous reflection with negative polarity, suggesting the presence of weaker or less dense sediments within or below the décollement. Taira, Hill, Firth, et al. (1991) were also able to successfully correlate the seismic reflection data with the lithologic and stratigraphic data obtained during Leg 131. In Figure 2 we emphasize three features of the seismic line related to the structure and hydrology at Site 808 .

First, the hemipelagic sequence above the décollement (the Upper Shikoku Basin sediments) progressively thins from 345 to $287 \mathrm{~m}$ (or about $17 \%$ ) as it is progressively overlain by the sediments of the outer marginal trench wedge (Fig. 2). We interpret this thinning to be a result of compaction and water loss and not stratigraphic thinning (see, for example, Bray and Karig, 1988; Shipley et al., 1990) for the following reasons: (1) the reflections within the hemipelagic sequence appear to converge landward - that is, individual reflections are more closely spaced where the sequence is thinnest; and (2) the mass accumulation rates of the hemipelagic sediments are several orders of magnitude lower than the marginal trench wedge sediments (Taira, Hill, Firth, et al., 1991). The equivalent hemipelagic sediments, therefore, would be several orders of magnitude thinner and probably not resolvable on the seismic reflection profile. If the original thickness of the hemipelagic sediments above the décollement is given by the vertical section just seaward of the trench (i.e., approximately $345 \mathrm{~m}$ ), then the hemipelagic sediments have lost about $17 \%$ of their original volume due to sedimentary loading and compaction prior to accretion. Direct evidence for fluid migration within this sequence is provided at Site 808 by the occurrence of a clastic dike and hydraulic breccia in the middle of the thinned hemi- 
pelagic sequence (Fig. 2, Byrne et al., this volume; Maltman et al., this volume). These dewatering structures also represent the only direct evidence for concentrated, or channelized, fluid flow at Site 808 .

As the hemipelagic sequence of the Upper Shikoku Basin enters the deformation front, however, its thickness increases from 287 to $373 \mathrm{~m}$ just landward of the frontal thrust (Fig. 2). That is, after the sediments have traveled nearly $4.5 \mathrm{~km}$ through the prism, they have thickened by almost $30 \%$. As discussed below, thickening appears to be accommodated by a combination of distributed and discrete deformational fabrics. For example, in the region just seaward of the frontal thrust (Fig. 2), displacements associated with four small fault splays can account for essentially all of the thickening of the hemipelagic sediments at this position (approximately 10\%). Moore et al. (1990) also recognized thickening of the hemipelagic sequence but considered most of the thickening to occur in the protothrust zone seaward of the frontal thrust. Our line drawing indicates that only a small amount of the thickening $(\sim 10 \%)$ occurs seaward of the frontal thrust.

Second, in contrast to the hemipelagic sediments above the décollement, the hemipelagic sediments below the décollement appear to maintain a constant thickness as they are underthrust. Approximately 2-3 km seaward of the tip of the décollement the underthrust sediments are approximately $550 \mathrm{~m}$ thick, whereas in the area landward of the frontal thrust they appear to have thinned by only a few meters, if at all (Fig. 2). Apparently, this constant thickness is maintained by an increase in pore-fluid pressure in the underthrust hemipelagic sediments. Porosity data from these sediments (Fig. 3) support this interpretation.

The final reason for including a line drawing of the seismic reflection profile is to provide an estimate the displacement along the décollement at Site 808. Of the 13 faults we recognized seaward of Site 808 , two appear to be relatively major (i.e., displacements are $>40 \mathrm{~m}$ ), whereas most have displacements ranging from $8 \mathrm{~m}$ (near the resolution of the seismic data) to $24 \mathrm{~m}$. The total displacement along the décollement at Site 808 , however, is nearly $170 \mathrm{~m}$. When considered with the thickness of the décollement $(19 \mathrm{~m})$ based on observations at Site 808, the décollement has a displacement/thickness (D/T) ratio of 8.94. This D/T ratio, although based on only one observation, is similar to the $\mathrm{D} / \mathrm{T}$ ratio for the frontal thrust of 10.3 (Taira, Hill, Firth, et al., 1991).

\section{Anisotropy of Magnetic Susceptibility}

Anisotropy of low-field magnetic susceptibility (AMS) was measured on about 120 samples between 300 and 1100 mbsf (Fig. 3; Owens, this volume). Anisotropy of magnetic susceptibility is commonly expressed by comparing susceptibility values in three perpendicular axes, much like the strain axes in structural geology. The values of these three axes define the magnetic susceptibility ellipsoid, which can vary in shape from oblate (maximum $=$ intermediate $>$ minimum) to prolate $($ maximum $>$ intermediate $=$ minimum $)($ Fig. 3) . Magnetic susceptibility ellipsoids are usually interpreted as indicating a statistical alignment of elongate or platy magnetic grains. A nonisotropic distribution of relatively spherical magnetic grains, however, may also produce a magnetic anisotropy. For example, elongate magnetite grains in a foliated shale may have their long axes rotated away from the shortening direction and toward the foliation as a result of the penetrative strain associated with foliation development. Alternatively, if volume loss is a significant component of the deformation, the distribution of even fairly spherical grains will become nonisotropic and yield an AMS ellipsoid. In this study we summarize three aspects of the AMS data that correlate particularly well with significant structural and physical property anomalies (Fig. 3).

One of the most striking results of the AMS study (Owens, this volume) is the marked contrast in the shape and orientation of the AMS ellipsoids above and below the décollement (Fig. 4 and "Ellipsoid shape" column in Fig. 3). Above the décollement the AMS ellipsoids have a substantial prolate component and the maximum susceptibility axes trend generally northeast. Below the décollement the ellipsoids are clearly oblate and a dominant direction in the trend of the maxima axes is not discernible (Fig. 4). Owens (this volume) considers these changes across the décollement to reflect the modification of an initial, bedding/compaction grain fabric (i.e., a nearly oblate fabric) by bedding-parallel, tectonic compression. These compressive strains may have been accommodated by substantial volume loss or they may have been constant-volume, plane strains. The near parallelism of the AMS ellipsoids with bedding (both generally dip less than $10^{\circ}$ ) suggest, however, that bedding-parallel shear and noncoaxial strains were not significant in generating the AMS ellipsoids.

A second important characteristic of the AMS data is that, although the AMS ellipsoids are generally flat-lying and parallel to bedding throughout Site 808, there are several exceptions (Fig. 3). Figure 3 shows four intervals (highlighted by arrows) where the maximum and intermediate axes of the AMS ellipsoids deviate significantly from horizontal. The intervals occur at about $365,550,800$, and between 940 and $960 \mathrm{mbsf}$, and correlate directly with intervals of steepened bedding (Fig. 3). These changes in dip also correlate with increase in the number of faults/meter (Fig. 3). We infer, therefore, that the AMS fabrics have been rotated with bedding as these intervals of concentrated deformation formed. That is, the AMS fabrics appear to predate the development of much of the brittle deformation characterized by the small faults. Owens (this volume) reached a similar conclusion based on a more detailed study of the AMS patterns in the syncline just below the frontal thrust.

A third significant feature of the magnetic susceptibility data is that the AMS ellipsoids are more prolate below 550 mbsf than above this depth. This depth also marks the lower limit of the kink-like deformation structures which typically predate the small faults and are folded by the frontal thrust (Taira, Hill, Firth, et al., 1991). These structures are therefore considered to have formed relatively early in the deformation history of the prism. One possible interpretation of these observations is that the bedding-parallel compression that modified the initial bedding/compaction fabric was partitioned into two regimes. Above about $550 \mathrm{mbsf}$, where the sediments are relatively fissile, the bedding-parallel compression resulted in the formation of kink-like structures and penetrative strains only slightly modified the initial bedding fabric. Below this level, the sediments are less fissile and penetrative strains are more significant.

An alternative interpretation is that the initial bedding/compaction fabrics may not have been identical above and below this level and the different AMS ellipsoids may simply reflect the different lithologies across this boundary. For example, an initially prolate ellipsoid might have been produced by sedimentary currents parallel to the Nankai Trough (which generally trends northeast). This initial prolate ellipsoid would have been accentuated by bedding-parallel compression. This possibility seems unlikely, however, because the sediments most likely to preserve a depositional (or current-generated) fabric are the relatively coarse-grained and phyllosilicate-rich sediments above $550 \mathrm{mbsf}$ and these sediments have the most oblate AMS ellipsoids. Strain partitioning during bedding-parallel compression, therefore, is considered to be a reasonable interpretation (see also Taira and Niitsuma, 1986).

Finally, the AMS data are also consistent with the structural and physical property data at a more detailed scale. Three examples from $783 \mathrm{mbsf}, 816 \mathrm{mbsf}$, and $940 \mathrm{mbsf}$ are summarized in Figure $4 \mathrm{C}$. The sample from $783 \mathrm{mbsf}$ has a maximum susceptibility axis that trends northeast, parallel to most of the other maxima above the décollement. The intermediate axis for this sample, however, has a much more shallow plunge than the other data (Fig. 4C). Because this sample comes from an interval of increased bedding dip (at $780 \mathrm{mbsf}$ ), it seems reasonable to propose that the susceptibility ellipsoid rotated with bedding during southeast-directed shearing. The second and third examples, from $816 \mathrm{mbsf}$ and $940 \mathrm{mbsf}$ (Fig. 4), have suscepti- 


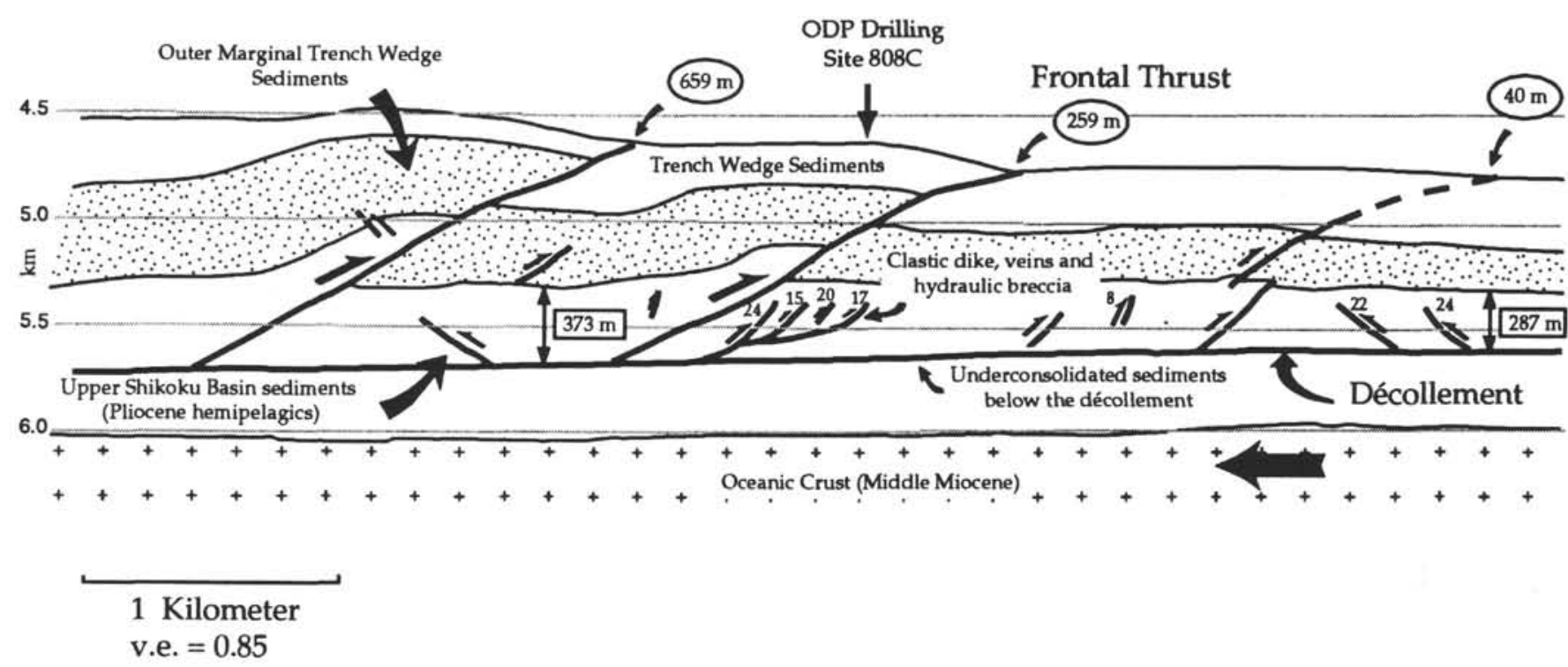

Figure 2. Line drawing of migrated seismic line NT62-8 from Taira, Hill, Firth, et al. (1991; see also Moore, et al., 1990). Circled numbers show magnitudes of horizontal displacements of major thrust faults based on the seismic reflection profile. For comparison, Leg 131 documented $267 \mathrm{~m}$ of horizontal displacement (vs. the $259 \mathrm{~m}$ shown here) along the frontal thrust based on offset conglomerate and carbonate horizons. Uncircled numbers show horizontal displacements on relatively smaller faults. Note that the total horizontal displacement along the décollement at Site 808 is approximately $170 \mathrm{~m}$. Also, we have extended the Upper Shikoku Basin sediments to a depth nearly equivalent to the décollement based on the character of this unit on the seismic reflection profile (Taira, Hill, Firth, et al., 1991; Moore et al., 1990); Figure 3 shows these sediments extending only to bottom of the last recognized ash layer.

bility axes that appear to have rotated approximately $90^{\circ}$ about a vertical axis, relative to a normal or expected susceptibility axis. These two samples, however, come from intervals where along-strike shortening has been documented (Fig. 3). We, therefore, consider the anomalous trends of these AMS maxima to be a result of along-strike shortening and not rotation about a vertical axis.

In total, the AMS data show excellent correlations with the structural data. The dominant fabric in both data sets reflect northwest-directed shortening with smaller intervals recording southeast-directed shearing or along-strike shortening. Oriented $P$-wave velocity data also show a horizontal anisotropy that is consistent with these results.

\section{$\boldsymbol{P}$-wave Velocity Data}

Compressional velocities were measured at approximately $70 \mathrm{~cm}$ intervals in two directions: parallel (or longitudinal) and perpendicular (or transverse) to the axis of the core barrel. These data, by themselves, allow for the calculation of the acoustic anisotropy of the sediments, and Taira, Hill, Firth, et al. (1991) report anisotropies of between 5\% and $10 \%$ for the sediments above the décollement (see also Brückmann et al., this volume). The orientation of the anisotropy in a horizontal plane is unconstrained, however, because all of the samples were rotated about a vertical axis during drilling.

To correct for this drilling-induced rotation Byrne et al. (this volume; see also Brückmann et al., this volume, for a slightly different analysis of a more selected data set) applied a "paleomagnetic correction" to each velocity measurement based on a mean declination value as determined from the magnetic remanence of the cores. This correction is possible because the transverse velocity measurements were routinely made in the same orientation relative to a mark on the core liner (a double line parallel to the core axis). This mark was also used as a reference for paleomagnetic and structural measurements.

In orienting the velocity data both the natural remanent magnetization and the magnetic remanence after alternating field demagneti- zation were used to evaluate the stability and reliability of the paleomagnetic pole. Alternating field demagnetization was applied over a $10-$ to $30-\mathrm{cm}$ interval that included the site sampled for transverse velocity (see Taira, Hill, Firth, et al., 1991, for discussion of shipboard paleomagnetic techniques and results). If the paleomagnetic remanence was consistent in declination, inclination, and intensity over this interval it was considered reliable and the mean declination for the interval was calculated. This declination was used to determine the true orientation of the transverse velocity data, as well as any structural features that occurred in this interval.

Byrne et al. (this volume) also attempted to account for variation in velocities due to changes in lithologies by including only samples that were described as homogeneous silty clay. This eliminated most of the relatively coarse-grained turbidites in the upper section of Site 808 . We also eliminated velocity data from a $50-\mathrm{m}$ interval between 778 and 823 mbsf that contained an unusually large number of high velocities (Fig. 3, "Acoustic velocity" columns). This interval also contained an unusually high concentration of faults, some of which record along-strike shortening (Fig. 3), several carbonate layers, and the only clastic dike and hydrofracture observed at Site 808 . The resulting velocity data were binned over $10^{\circ}$ intervals. In total, approximately 350 velocity analyses and paleomagnetic poles from 600 to $110 \mathrm{mbsf}$ are represented in Figure 5 with about two-thirds of the data coming from above the décollement.

The scatter plot of oriented and binned velocity data show a clear difference in the horizontal velocities above and below the décollement (Fig. 5). Above the décollement the velocity data show a peak of about $2200 \mathrm{~km} / \mathrm{s}$ that trends northeast (roughly $050^{\circ}$ ). There is also a well-developed low in the velocity data approximately $90^{\circ}$ from the velocity maximum. These velocity maxima and minima are nearly perpendicular and parallel, respectively, to the inferred direction of plate convergence (about $308^{\circ}$ to $315^{\circ}$ ). Below the décollement the binned horizontal velocity data are much more scattered and the transverse velocities appear isotropic. 


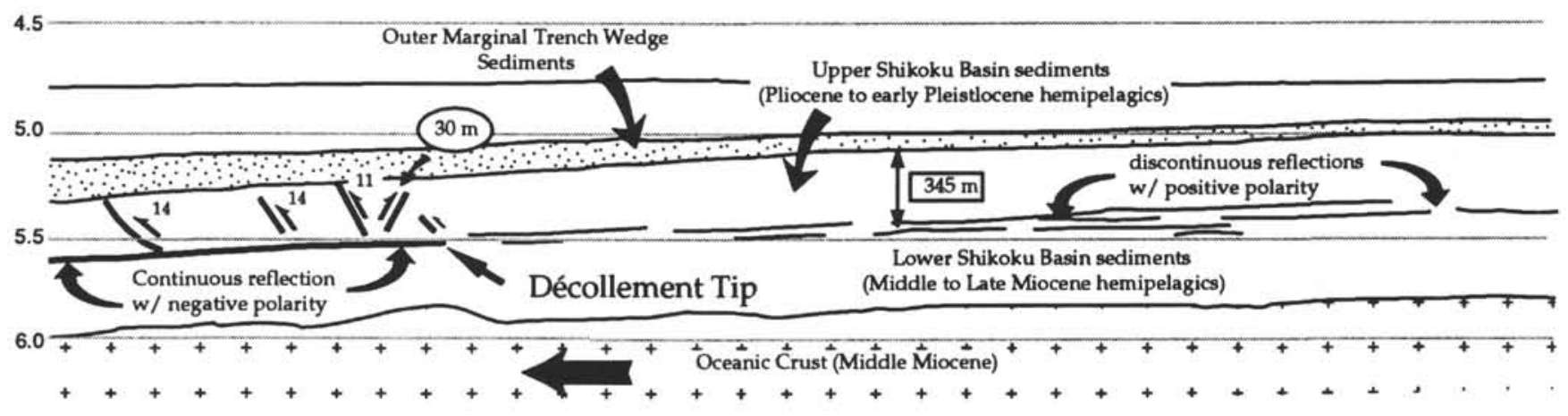

Figure 2 (continued).

Although the coincidence of the directions of velocity anisotropy and the plate convergence vectors suggest a tectonic origin, a specific origin for the anisotropy is difficult to infer from the velocity data alone. For example, the anisotropy may be related to a penetrative deformation that was associated with dewatering of the silts and clays, as we prefer. On the other hand, the fabric may reflect a penetrative microcracking that, although related to plate convergence, may not have been associated with dewatering of the sediments. The magnetic susceptibility data presented above indicate, however, that the former interpretation is more likely.

Finally, Brückmann et al. (this volume) have oriented a subset of the velocity anisotropy (defined as the difference between the vertical and horizontal velocities expressed as a percentage of the mean velocity; Taira, Hill, Firth, et al., 1991) data and reached a slightly different conclusion for the velocity anisotropy above the décollement. These authors selected only velocity values between 823 and $935 \mathrm{mbsf}$ and the data suggest two directions of relatively high velocities. One direction trends northeast, similar to the results we have presented, whereas the second trends northwest. In considering the structural and magnetic susceptibility data in the 20 to $30 \mathrm{~m}$ above the décollement (Figs. 3, 4, and 7), it seems reasonable to conclude that the interval included by Brückmann et al. (this volume) contained an equal sampling of high velocities that trend northeast and northwest, whereas in the interval summarized in Figure 5A (from 600 to $935 \mathrm{mbsf}$ ) the northwest-trending high velocities are a relatively minor component.

In total, the seismic reflection, AMS, velocity, and porosity data reveal significantly different histories for the sediments above and below the décollement. Above the décollement the sediments are progressively consolidated by both sedimentary loading and tectonic stresses related to plate convergence. At least locally, the fluids were channelized, forming clastic dikes, veins, and hydraulic breccia. Below the décollement, the sediments, although similar in composition, are much less consolidated and the penetrative fabrics present reflect a relatively minor component of vertical loading (e.g., the oblate susceptibility ellipsoids, Fig. 3). Most importantly, the constant thickness of the hemipelagic sediments below the décollement (Fig. 2 ) indicates that these sediments have not substantially dewatered. This constant thickness is apparently maintained by an increase in pore-fluid pressures within the underthrust sediments.

\section{CORE-SCALE STRUCTURES AND EVIDENCE FOR SHEAR-ENHANCED CONSOLIDATION}

Results presented in the previous chapters on core-scale structures suggest two main conclusions: (1) most of the core-scale structures are associated with substantial reorientation of the primary phyllosilicate fabric that apparently resulted in consolidation and dewatering within these zones, and (2) the kinematics of the core-scale structures argue for a relatively simple stress regime that is consistent with the plate convergence vector, although notable exceptions are also present. Although detailed description of these structures are presented in Byrne et al. (this volume) and Maltman et al. (this volume), we present here a brief summary of typical kink-like bands, small faults, and scaly clays from the décollement because these structures appear to have played a significant role in prism tectonics and hydrology.

\section{Kink-like Bands and Small Faults}

Kink-like deformation bands are the oldest and second most abundant structure recognized at Site 808 (Fig. 3). Macroscopically they are diffusely bounded zones that are slightly darker than the surrounding material, but they are rarely as dark as the small faults (Byrne et al., this volume; Maltman et al., this volume). The bands are commonly 1 to $2 \mathrm{~mm}$ in cross-sectional width, although some examples reach 1 to $2 \mathrm{~cm}$. The bands typically offset adjacent marker horizons (e.g., bedding) although displacements, where documented, are relatively small (less than a few millimeters) even when the bands are relatively wide and well developed. All of the documented displacements record contractional strains relative to bedding. When corrected with paleomagnetic data for rotations due to drilling, the kink-like structures strike northeast and dip either northwest or southeast. We therefore have inferred that the shortening direction associated with kinks trends northwest, approximately parallel to the plate convergence vector.

At a microscopic scale, the kink-like structures display a substantial amount of substructure and are rarely simple parallel-sided bands with consistently oriented (or deflected) internal fabric (see also Karig and Lundberg, 1990). Although there is a wide variety of substructure, all of the structures appear to be essentially normal faults relative to the boundaries of the kink-like bands. The normal faults occur at a 


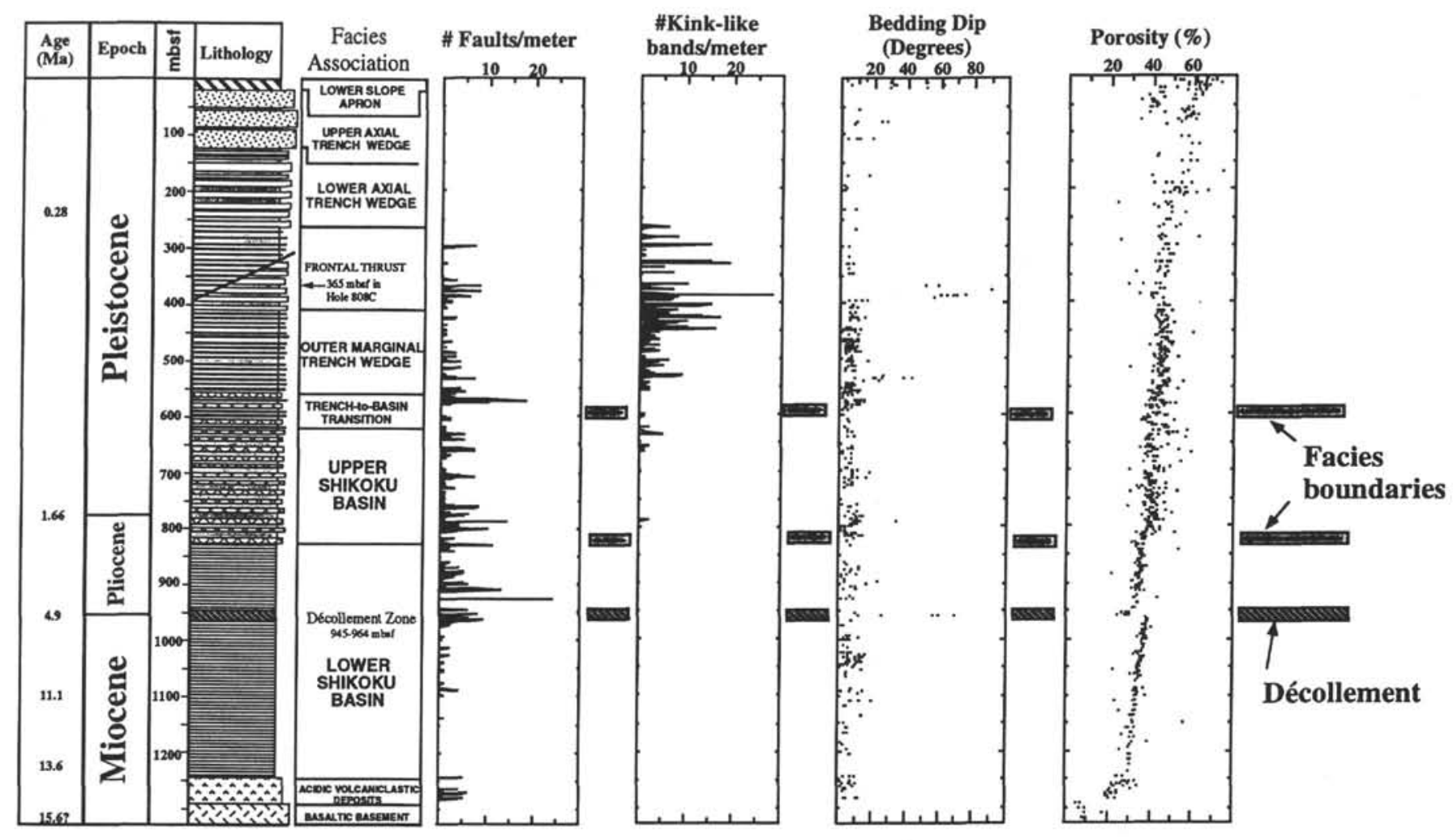

Figure 3. Synthetic correlation diagram of stratigraphic, structural, physical property, and magnetic data from Site 808 . Note the correlation between the change in shape of the magnetic anisotropy ellipsoid from slightly oblate to more prolate at about 550 mbsf with the lower limit of kink-like structures and outer marginal trench-wedge sediments. Note also the local occurrence of along-strike shortening and normal faulting between 600 and 950 mbsf. Sense of slip, and thus $P$ and $T$, below the décollement are poorly constrained. The stereonet shows the technique for determining $P$ and $T$ axes from fault and slickenline data. The Upper Shikoku Basin sediment facies at Site 808 ("Facies association" column) is defined differently than it is by Moore et al. (1990), who based their interpretations only on seismic reflection profile NT62-8 (see Taira, Hill, Firth, et al., 1991, "Site 808" chapter, back-pocket fig. 155). This lack of correlation between drilling and seismic reflection data may simply reflect the lack of recovered ash layers below about $800 \mathrm{mbsf}$ at Site 808 .

low angle to the bands (approximately $15^{\circ}$ ) and display a phyllosilicate fabric that is much more concentrated and well developed than the fabrics within or external to the kink-like structure. Byrne et al. (this volume) interpret the normal faults to be Riedel shears or Mohr-Coulomb instabilities that formed with the kink-like structures.

An aspect of the kink-like structures that may be particularly important for the hydrology of the sediments is that all of these structures appear to have intensified or concentrated the primary phyllosilicate fabric. This can be seen more quantitatively by comparing the internal and external angles of the ODP kink-like structures to similar angles in more classic kink bands (Byrne et al., this volume). The ODP structures have a generally constant external angle $(\gamma=45)$ but a highly variable internal angle $\left(\gamma_{\mathrm{k}} \leq 45^{\circ}\right)$ which, in part, reflects the development of the Riedel shears described above. The relatively low internal angles for the ODP kink-like structures indicates a decrease in volume for these structures (see review in Suppe, 1985). Computer tomographic X-ray data, summarized below, also indicate a decrease in volume within these zones.

In contrast to the kink-like structures, the small faults are typically narrow $(<1 \mathrm{~mm})$, sharply bounded zones of displacement that appear much darker than either the kink-like structures or the surrounding sediments (Taira, Hill, Firth, et al., 1991; Maltman et al., this volume). At the scale of the core barrel, the faults extend for several centimeters and record displacements of a few to $>7 \mathrm{~mm}$. The fault surfaces have a polished appearance to various degrees and are commonly lineated. The small faults may record normal, strike-slip, or reverse motion, although moderate to low-angle thrust are the most common (see "Shortening axes" columns in Fig. 3).
In three dimensions, the faults have more complex geometries than the kink-like structures (Fig. 3). In general, the faults dip moderately to gently with wide variations in strike, resulting in a generally lowdipping fabric composed of a web of intersecting faults. In some cases the faults form conjugate sets, and Lallemant et al. (this volume) have recognized a decrease in the dihedral angle of different conjugate sets with depth. They have proposed that this change reflects an increase in pore pressure or a change in the physical properties of the sediments with depth. They also note specifically the decrease in dihedral angles within the hemipelagic sediments.

At a microscopic scale the small faults are characterized by thin to thick zones of very well-developed phyllosilicate fabric that roughly parallels the fault zone boundary. Although many of the phyllosilicates within the zone are subparallel to the zone boundaries, there is also a secondary fabric that is equally pervasive but inclined at a low angle to the zone boundaries. This fabric has a geometry that is consistent with Riedel shears. In total, the well-developed phyllosilicate fabrics within these faults suggest substantial consolidation relative to the surrounding, less-deformed sediments. Consolidation and dewatering of the small faults are also indicated by X-ray tomography studies.

\section{Scaly Clays from the Décollement}

As summarized by Maltman et al. (this volume) the décollement zone appears to be characterized by a curious mottled or domainal texture at both core- and thin-section scales. The mottled texture is defined by an irregular and discontinuous set of shear surfaces that surround zones of relatively undeformed silt and clay. The shear 
Figure 3 (continued).

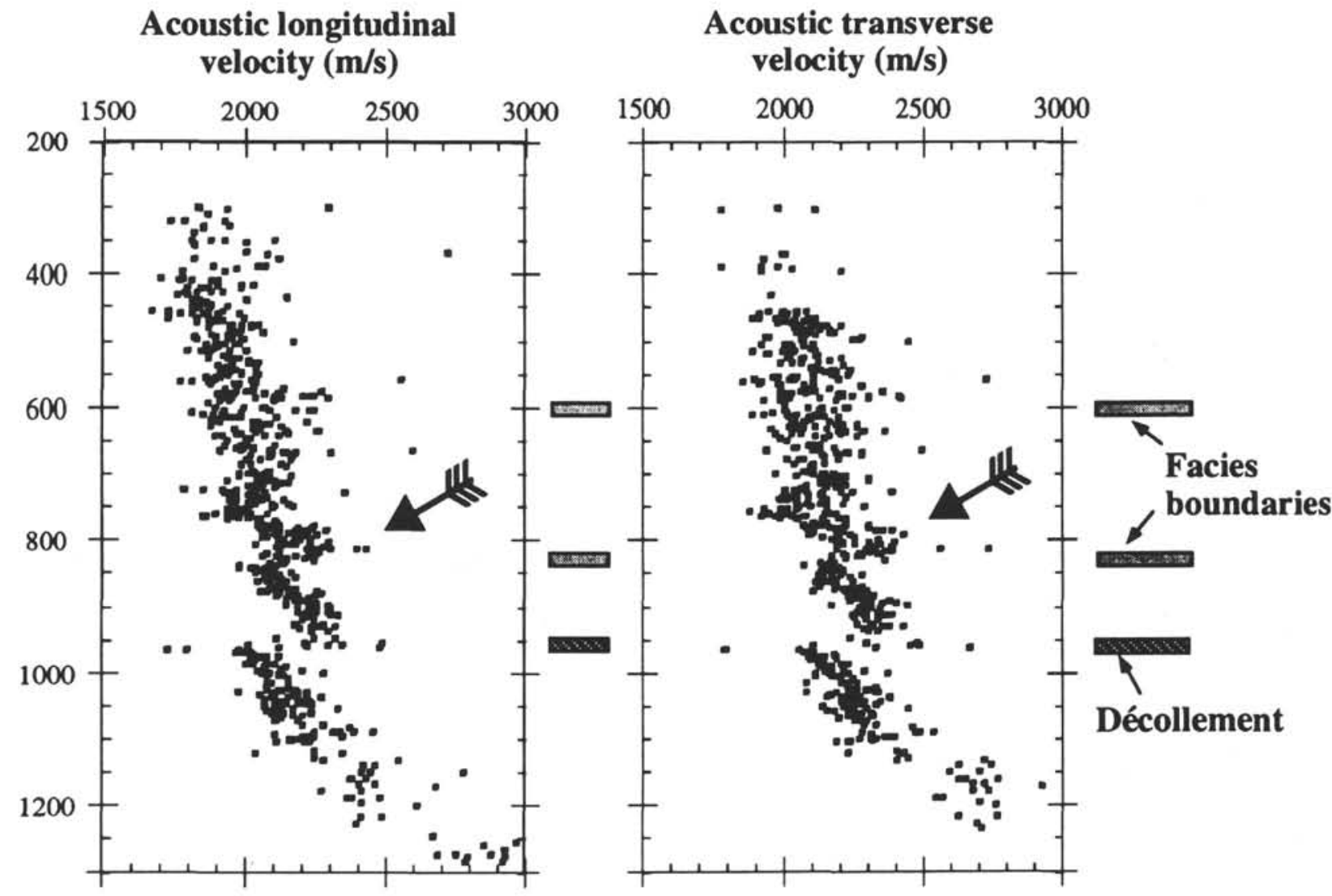

Acoustic transverse velocity $(\mathrm{m} / \mathrm{s})$ surfaces are different from the faults and kink-like bands in that they are much thinner, more irregular in orientation, and more discontinuous. These domains of deformed and undeformed clays are also conspicuous at the scale of transmission electron microscopy (TEM) (see Maltman et al. this volume). TEM observations reveal the presence of zones of brecciation and a collapsed phyllosilicate framework within the shear surfaces discussed above. The breccia fragments appear to be composed of clasts that contain a fabric created during an earlier deformation event in the décollement zone, suggesting multiple episodes of deformation.

Based on the microscopic, TEM, and X-ray scanning data, Byrne et al. (this volume) have suggested a cyclic deformation sequence for the scaly clays in the décollement. This cycle involves displacementbrecciation-porosity collapse and compaction. These authors also proposed that this cycle is driven by pulses of increased fluid pressure. Consequently, they have inferred that the cyclic deformation was associated with a changing permeability behavior as the sample progressively consolidated.

\section{X-ray Computed Tomography Results}

To more precisely define the three-dimensional image and, in particular, to document the density structure of the deformational structures in the Nankai sediments, Soh et al. (this volume) (see also Byrne et al., this volume) scanned and computed X-ray tomographic images of 21 samples from Site 808. The samples included 19 mudstones and two greenstones. Of the 21 samples, approximately half were whole-round cores, ranging from 5 to $45 \mathrm{~cm}$ long. The remaining samples were relatively small chips collected for fabric analysis. In total, about 150 tomographic images were constructed.

The computed tomography study of samples yielded two main results: (1) there is a positive correlation between increasing density and increasing attenuation coefficients for individual samples, and (2) within any deformed sample the attenuation coefficient is higher within the zone of deformation than it is in the undeformed matrix. Taken together these results indicate that the deformation zones record a density increase; Byrne et al. (this volume) and Soh et al. (this volume) have proposed that this change in density is related to consolidation and dewatering of the deformation structures.

Soh et al. (this volume) also completed a CT scan of a sample from the décollement zone (Sample 131-808C-69R-2, 72-74 cm), yielding two significant results. First, the CT numbers and the corresponding attenuation coefficients are the highest measured at Site 808, including the measurements from within the deformation zones at shallower levels. Apparently, the décollement contains some of the most dense sediments drilled at Site 808; this result is also consistent with the relatively high densities and low porosities measured on the JOIDES Resolution. Second, although the sample analyzed was relatively small, it does not appear to contain discrete zones of deformation. Instead, the CT images show a more homogeneous, but relatively dense, internal structure. Presumably, the small slip surfaces observed in thin sections are simply not resolvable at the scale of the X-ray tomography. This is consistent with the theoretical resolution of the $\mathrm{X}$-ray scanning machine, which is $1-2 \mathrm{~mm}$.

\section{Experimental Studies}

Finally, experimental studies of samples retrieved from Site 808 are also consistent with consolidation during deformation (Byrne et al., this volume). Byrne et al. (this volume) presented results of an experimental setup devised such that the rate of flow through the samples could be measured while the samples were at rest, or undeformed, and then continuously monitored during deformation. Although it seems to be clear that the experiments conducted while the 


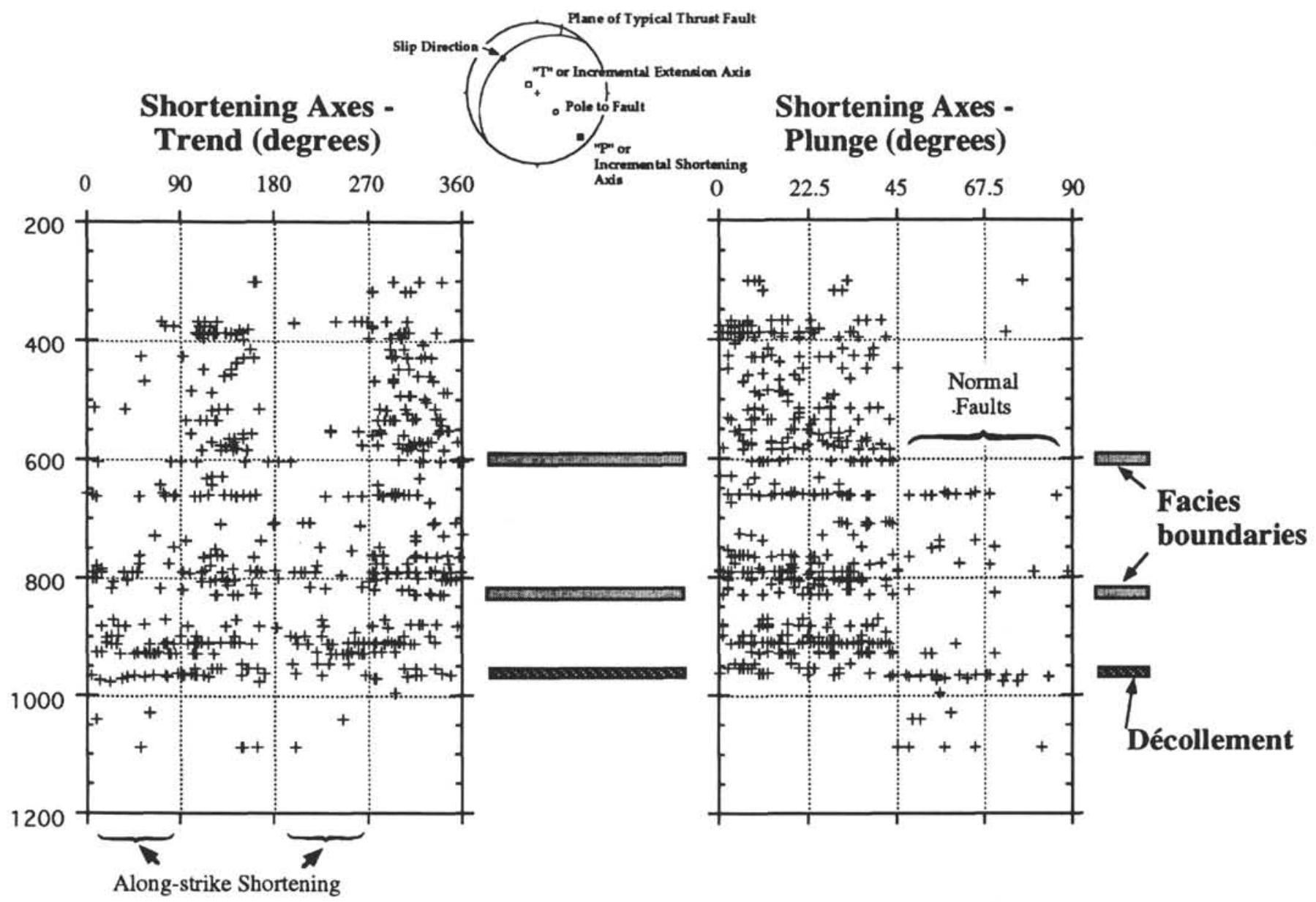

Figure 3 (continued).

samples were "at rest" allow calculation of the samples' permeability (Byrne et al., this volume), the significance of an observed increase in flow rate as the sample fails is less clear. At present, the simplest interpretation is that the increase in fluid flow at failure reflects consolidation of the sample. That is, the increase in flow is transient and not an indication of an increase in the samples' bulk hydraulic conductivity or permeability. We therefore consider these results to provide an experimental analog for tectonic consolidation, or shearenhanced dewatering, of the Nankai prism.

\section{KINEMATICS AND STRESS INVERSION}

The second major result of the structural studies is the consistent kinematics throughout the site and the good correlation between these kinematics and the plate convergence vector (Lallemant et al., this volume). To emphasize this point we have plotted the trend and plunge of the incremental shortening axes vs. depth in Figure 3 (see "Shortening axes - trend and plunge" columns). The incremental shortening axes (or $P$ axes) were determined for each fault plane and its associated slickenline following Marrett and Allmendinger (1990) (see also stereonet in Fig. 3). Plotting the incremental shortening axes is more convenient for investigating the kinematics at different depths below the seafloor than finding the mean slickenline or fault plane because each fault and slickenline can be represented with a single axis.

There are two main points to emphasize with the results of Figures 1 and 3. First, most of the shortening axes trend northwest or southeast, consistent with a plate convergence vector that the trends between $308^{\circ}$ and $315^{\circ}$ (Lallemant et al., this volume). A histogram of the shortening trends (Fig. 6) shows this result in more detail and has a bimodal distribution with peaks at $300^{\circ}$ to $315^{\circ}$ and $112^{\circ}$ to $135^{\circ}$. These trends compare favorably with the trends of $\sigma_{1}$ based on the stress tensor inversion method of Angelier (1984) and summarized in Figure 7. The much broader distribution of extension axes (Fig. 6) probably reflects the three-dimensional complexity of the small faults and the occurrence of strike-slip faults in some parts of the drilled section. The second main result is the presence of several anomalies in the trend and plunge of the shortening directions between about 600 mbsf and the décollement. Four anomalous intervals are recognized (Fig. 3): two intervals of along-strike shortening at about 800 and 940 mbsf (or just above the décollement) and two zones of normal faulting at about 650 and $750 \mathrm{mbsf}$. These four intervals were also documented by Lallemant et al. (this volume) using the stress inversion technique, although we have only included an example of their stress data for the anomalous interval just above the décollement in Figure 7. In total, the consistent results throughout Site 808 and the consistent results from different techniques are encouraging and suggest that we have accurately documented the kinematics at Site 808 .

\section{DISCUSSION}

The results and data presented above can be summarized in four basic observations relevant to the deformation and dewatering history of the prism sediments. First, in the upper part of the prism, three generally time-transgressive structural features were documented: (1) penetrative fabrics and kink-like structures, (2) small, core-scale faults, and (3) the frontal thrust. Second, the sediments above the décollement are overconsolidated relative to the sediments below the décollement and probably relative to a normal marine sedimentary 


\section{Dip of Max/Int Plane}

Degree of
Anisotropy
Ellipsoid

Shape

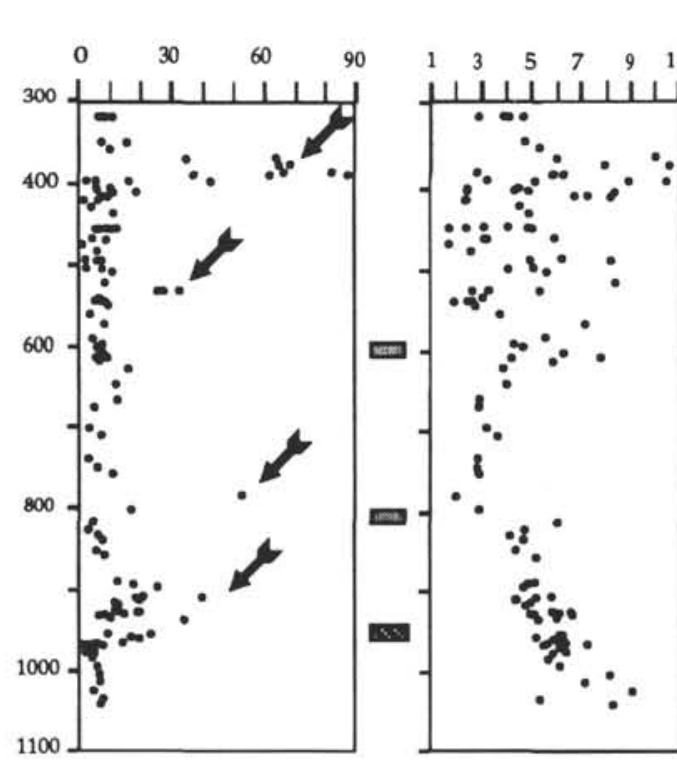

Oblate

Prolate

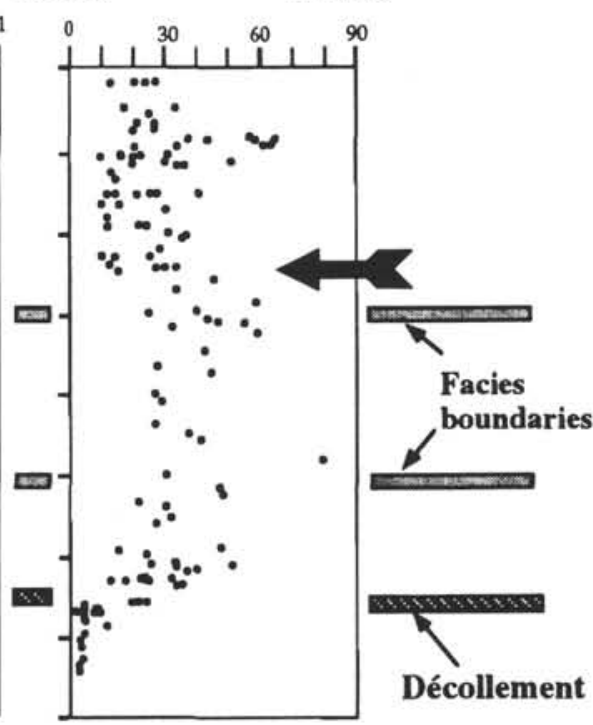

Figure 3 (continued).

sequence (Taira, Hill, Firth, et al., 1991). The sediments below the décollement also appear to be overpressured. Third, the décollement is defined by a 19-m-thick zone of highly faulted sediments with anomalously low porosities that record cyclic periods of overpressuring, deformation, and consolidation. Fourth, detailed CT-scans of the faults, kink-like structures (e.g., Fig. 3), and samples of the décollement consistently show that these deformation zones are more dense and less porous than any of the other sediments collected from Site 808 .

Figure 8 summarizes the possible significance of these observations. The progressive development of the penetrative fabrics, small faults, and frontal thrust is also interpreted following the concepts of critical state theory because of the need to incorporate porosity changes during deformation (Fig. 8B) (Schofield and Wroth, 1968; Brandon, 1984; Wong et al., 1992). In this interpretation the sediments initially follow a uniaxial compaction stress path (segment "a" in Fig. $8 \mathrm{~B})$. As the deformation front is approached, deviatoric stress increases, resulting in a steepening of the stress path (segment " $\mathrm{b}$ " in Fig. 8B), and the principal stresses reorient (not shown in Fig. 8B for simplicity). The reoriented stresses result in a reorientation of the penetrative and compactive phyllosilicate fabric from bedding-parallel to nearly bedding perpendicular ("Stage b" in Fig. 8B) as recorded by magnetic susceptibility and sonic velocity data (Owens, this volume; Byrne et al., this volume). As the mean and deviatoric stresses continue to increase, the stress path ultimately reaches the yield surface (marked by different porosities in Fig. 8B) for the sediments, and the dominant deformation mechanism changes from intergranular dewatering (or Darcian flow) and consolidation to shear-enhanced compaction (see, for example, Wong et al., 1992). In the Nankai sediments this transition is interpreted to be recorded by the change from penetrative fabrics to distributed faulting ("Stage c" in Fig. 8A). The increase in density within the fault zones argues for a strain-hardening stress path (e.g., "b" to "c" in Fig. 8B). With higher mean and deviatoric stresses the yield surface migrates (as the porosity decreases) and the sediments continue to strain-harden. Ultimately, the stress path crosses the critical state line and shear localization occurs ("d" in Fig. 8B). This stress state may correlate with the initiation of the frontal thrust ("Stage d" in Fig. 8A).
The dewatering and deformation history of the sediments within the décollement, in contrast, appears to be more cyclic and less systematic (Byrne et al., this volume; Maltman et al., this volume). Samples from the décollement are distinctively "mottled" and display a domainal texture at both microscopic and submicroscopic scales. The shear surfaces are typically much thinner and more irregular and discontinuous than similar surfaces from above the décollement. The décollement samples also appear to record cyclic events of brecciation and fabric collapse and the zones of fabric collapse are more disseminated throughout the sample. Both of these differences probably account for the greater density of the décollement samples.

The fundamentally different deformation histories for sediments above and within the décollement probably reflects the different structural positions and different fluid histories of the two suites of rocks. Specifically, we propose that the décollement zone is repeatedly deformed as overpressured fluids leak upward from the underlying Lower Shikoku Basin sediments. In contrast, individual fault zones and structures above the décollement have experienced only one deformation episode. We therefore consider the décollement to be a zone of relatively low shear stress that fails episodically as pulses of overpressuring migrate upward from the underthrust sediments. It is important to emphasize that, if the fluid pathways remain generally connected between the underthrust sediments and the décollement, fluid migration is not required between the underthrust sediments and the décollement, only the pulse of overpressuring needs to migrate to cause failure. In fact, the relatively low porosities within the décollement indicate fluids have generally moved out of this zone as deformation occurred. Local hydraulic gradients may have driven these fluids up- or downsection.

In total, the Nankai accretionary prism appears to be composed of three structural/hydrologic regimes (Fig. 8). A regime above the décollement is characterized by sediments that are progressively dewatered through the development of both penetrative fabrics and a pervasive, but apparently poorly interconnected, set of core-scale deformation structures (i.e., faults and kink-like structures). In this regime individual structures probably strain-harden (e.g., Moore and Byrne, 1987), and shortening is accommodated by the formation of 


\section{ANISOTROPY OF MAGNETIC SUSCEPTIBILITY}

A)

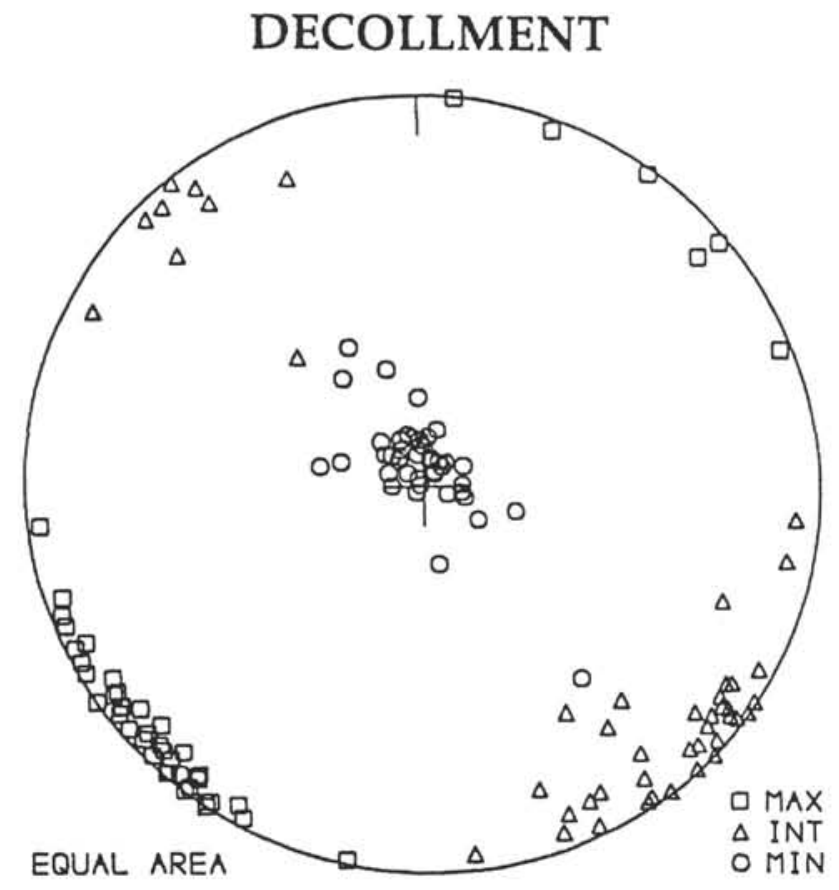

B)

\section{BELOW DECOLLMENT}

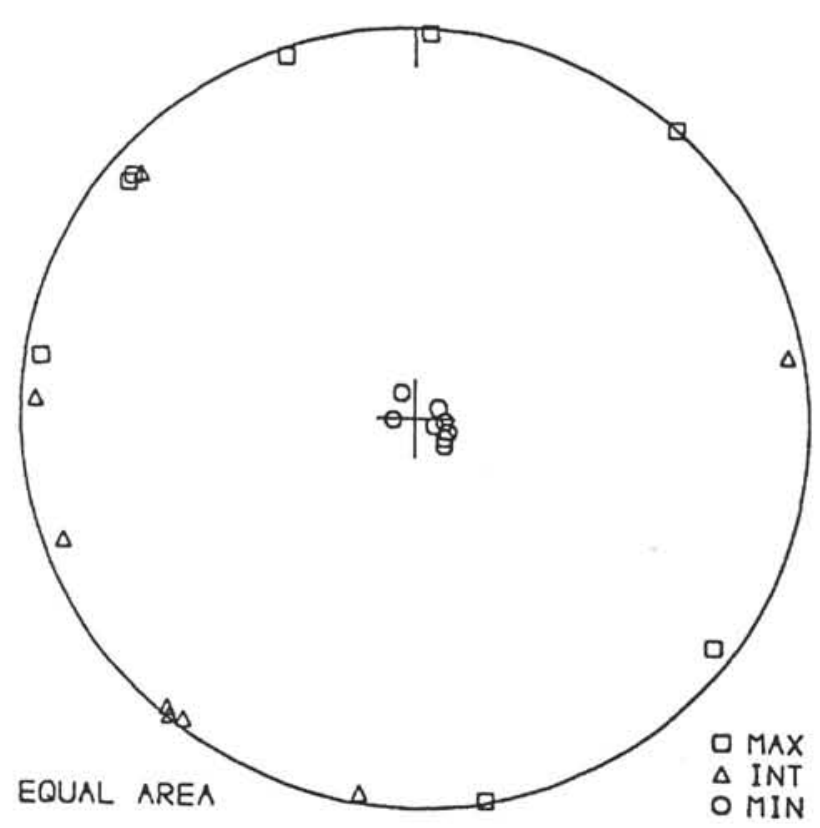

C) Anomalous Susceptibility Axes

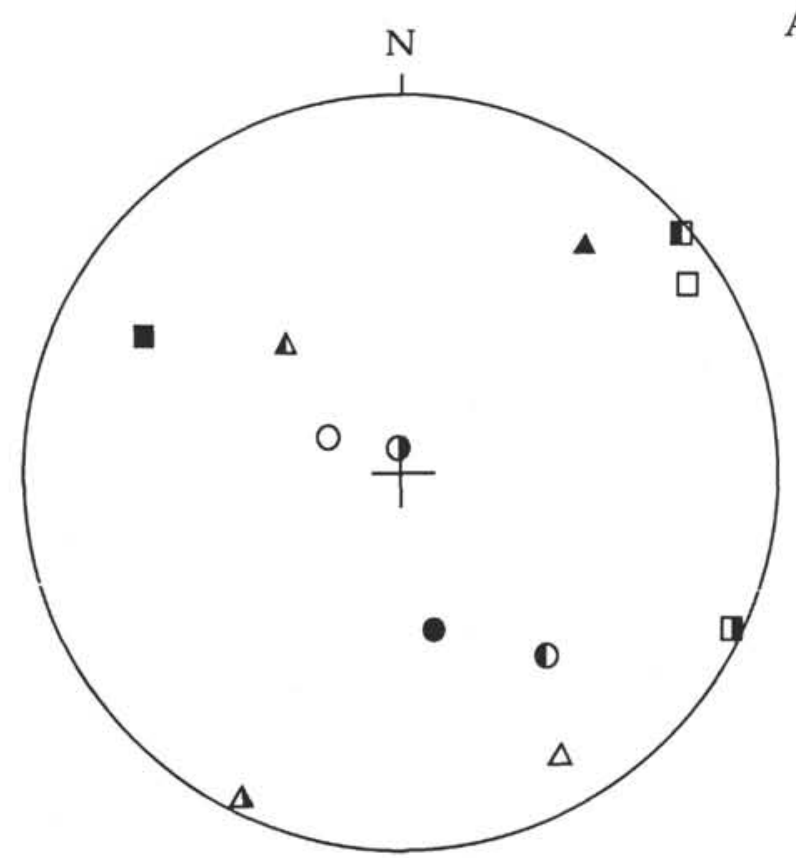

Anomalous Data

- A 940 mbsf (along-strike shortening or rotation about a vertical axes)

【 $\Delta$ - $816 \mathrm{mbsf}$ (along-strike shortening or rotation about a vertical axes)

D $\triangle \quad 783$ mbsf (possible rotation about NE-trending horizontal axes)

Expected Data (for comparison)

$\square \triangle O \quad 800$ mbsf ("normal")

Susceptibility Axes

$\square$ Maximum

$\Delta$ Intermediate

O Minimum

Figure 4. Stereonet showing the trend and plunge of the axes of maximum magnetic susceptibility above (A) and below (B) the décollement. Axes of anomalous susceptibility axes (maximum, minimum, and intermediate) from $783 \mathrm{mbsf}, 816 \mathrm{mbsf}$, and $940 \mathrm{mbsf}$ are shown in stereonet (C). The expected susceptibility axes for sediments at Site 808 are also shown for reference. 
new structures elsewhere in the prism, resulting in a structure distribution of about 5 structures/meter (Fig. 3). The décollement is characterized by a much higher density of structures/meter (probably an order of magnitude higher), and this regime is considered to be a zone of low stress but frequent failure. Individual deformation zones also probably strain-harden in this regime but, because the entire regime is at least episodically overpressured, potential failure surfaces are as pervasive as any fluid phase that is present. Hydrologically the décollement retards the vertical flow of fluids and enhances the potential for overpressuring in the footwall because episodic failure progressively decreases the porosity, and thus probably also the hydraulic conductivity. Finally, the footwall regime contains very few tectonic structures and is essentially isolated from the subhorizontal stresses related to plate convergence. This regime provides an important component to the tectonics of the Nankai prism, however, because it supplies the overpressured fluids that cause failure of the décollement at relatively low shear stresses.

\section{ACKNOWLEDGMENTS}

Participation in ODP Leg 131 was supported by the National Science Foundations (U.S.A.) and the Natural Environmental Research Council (U.K.). Sample analysis (by Byrne) was supported by NSF and the Japanese Society for the Promotion of Science. We also thank Neil Lundberg and Jim Sample for careful, thoughtful reviews.

\section{REFERENCES*}

Angelier, J., 1984. Tectonic analysis of fault slip data sets. J. Geophys. Res., 9:5835-5848.

Bamford, D., and Nunn, K., 1979. In situ seismic measurements of crack anisotropy in the Carboniferous limestone of northwest England. Geophys. Prospect., 27:322-388.

Brandon, M.T, 1984. Deformational processes affecting unlithified sediments at active margins: a field study and structural model [Ph.D. thesis]. Univ. of Washington, Seattle.

Bray, C.J., and Karig, D.E., 1986. Physical properties of sediments from the Nankai Trough, Deep Sea Drilling Project Leg 87A, Sites 582 and 583. In Kagami, H., Karig, D.E., Coulbourn, W.T., et al., Init. Repts. DSDP, 87: Washington (U.S. Govt. Printing Office), 827-842.

1988. Dewatering and extensional deformation of the Shikoku Basin hemipelagic sediments in the Nankai Trough. Pure Appl. Geophys., 128:725-747.

Brown, K.M., and Westbrook, G.K., 1988. Mud diapirism and subcretion in the Barbados Ridge Complex. Tectonics, 7:613-640.
Fisher, D., and Byrne, T., 1987. Structural evolution of underthrusted sediments, Kodiak Islands, Alaska. Tectonics, 6:775-794.

Karig, D.E., and Lundberg, N., 1990. Deformation bands from the toe of the Nankai accretionary prism. J. Geophys. Res., 95:9099-9109.

Marrett, R., and Allmendinger, R., 1990. Kinematic analysis of fault-slip data. J. Struct. Geol., 12:973-986.

Moore, G.F., Shipley, T.H., Stoffa, P.L., Karig, D.E., Taira, A., Kuramoto, S., Tokuyama, H., and Suyehiro, K., 1990. Structure of the Nankai Trough accretionary zone from multichannel seismic reflection data. J. Geophys. Res., 95:8753-8765.

Moore, J.C., and Byrne, T., 1987. Thickening of fault zones: a mechanism of melange formation in accreting sediments. Geology, 15:1040-1043.

Moore, J.C., Mascle, A., et al., 1988. Proc. ODP, Sci. Results, 110: College Station TX (Ocean Drilling Program).

Moore, J.C., Roeske, S., Lundberg, N., Schoonmaker, J., Cowan, D., Gonzales, E., and Lucas, S., 1986. Scaly fabrics from Deep Sea Drilling Project cores from forearcs. In Moore, J.C. (Ed.), Structural Fabrics Preserved in Deep Sea Drilling Project Cores From Forearcs. Mem.-Geol. Soc. Am., 166:55-73.

Schofield, A., and Wroth, P., 1968. Critical State Soil Mechanics: New York (McGraw-Hill)

Shipley, T.H., Stoffa, P.L., and Dean, D.F., 1990. Underthrust sediments, fluid migration paths, and mud volcanoes associated with the accretionary wedge off Costa Rica: Middle America trench. J. Geophys. Res., 95:8743-8752.

Suppe, J., 1985. Principles of Structural Geology: Englewood Cliffs, NJ (Prentice-Hall).

Taira, A., Hill, I., Firth, J.V., et al., 1991. Proc. ODP, Init. Repts., 131: College Station, TX (Ocean Drilling Program).

Taira, A., Katto, J., Tashiro, M., Okamura, M., and Kodama, K., 1988. The Shimanto Belt in Shikoku, Japan: evolution of Cretaceous to Miocene accretionary prism. Mod. Geol., 12:5-46.

Taira, A., and Niitsuma, N., 1986. Turbidite sedimentation in the Nankai Trough as interpreted from magnetic fabric, grain size, and detrital modal analysis. In Kagami, H., Karig, D.E., Coulbourn, W.T., et al., Init. Repts. DSDP, 87: Washington (U.S. Govt. Printing Office), 611-632.

Wong, T.-F., Hiram, S., and Zhang, J., 1992. Effect of loading path and porosity on the failure mode of porous rocks. Appl. Mech. Rev., 45:281-293.

* Abbreviations for names of organizations and publications in ODP reference lists follow the style given in Chemical Abstracts Service Source Index (published by American Chemical Society).

Date of initial receipt: 19 May 1992

Date of acceptance: 29 October 1992

Ms 131SR-142 
A

Décollement

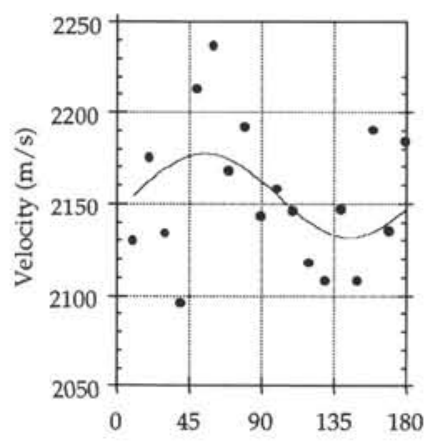

Orientation

(degrees from north)
B

\section{Décollement}

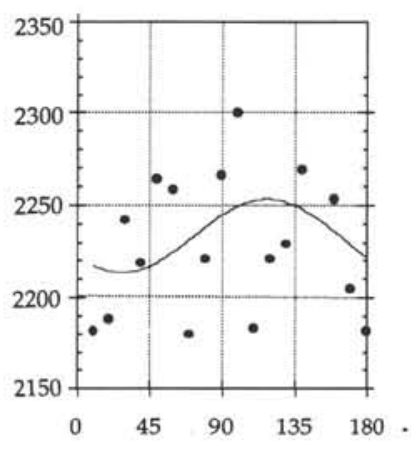

Orientation

(degrees from north)

Figure 5. $P$-wave velocity scattergram showing the variation in "binned" velocity vs. orientation. A. Oriented velocity data above the décollement. Note the well-developed peak in velocity in the data above the décollement with a trend of about N50E and the corresponding velocity low at about N40W. This azimuthal variation in velocity corresponds to a horizontal velocity anisotropy of about $2 \%$. B. In contrast, a well-developed velocity anisotropy does not appear to be present in the sediments below the décollement. Curves are best-fitting function of the different data sets, following Bamford and Nunn (1979; see also Byrne et al., this volume).

SHORTENING TRENDS

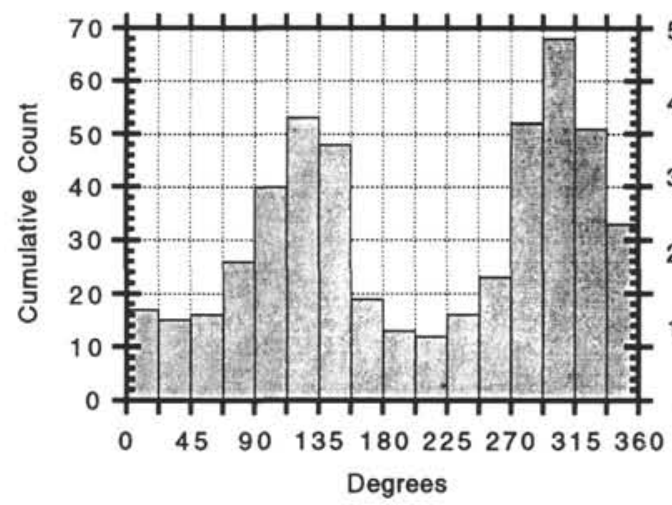

EXTENSION TRENDS

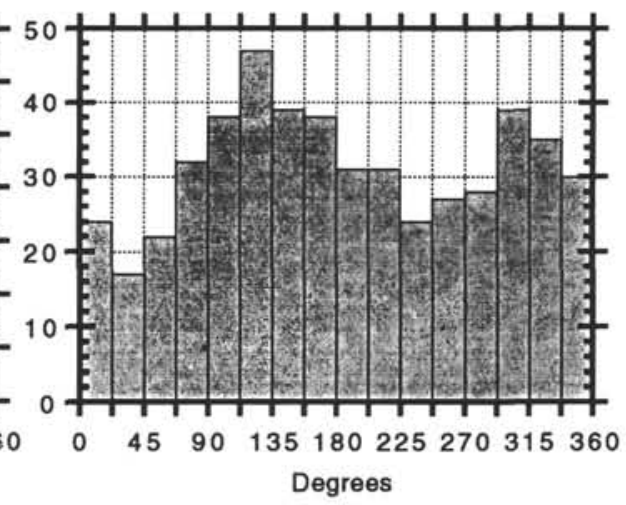

Figure 6. Histogram of $P$ (incremental shortening) and $T$ (incremental extension) axes from Site 808. For reference, the present-day convergence vector at Site 808 trends about $312^{\circ}$. 

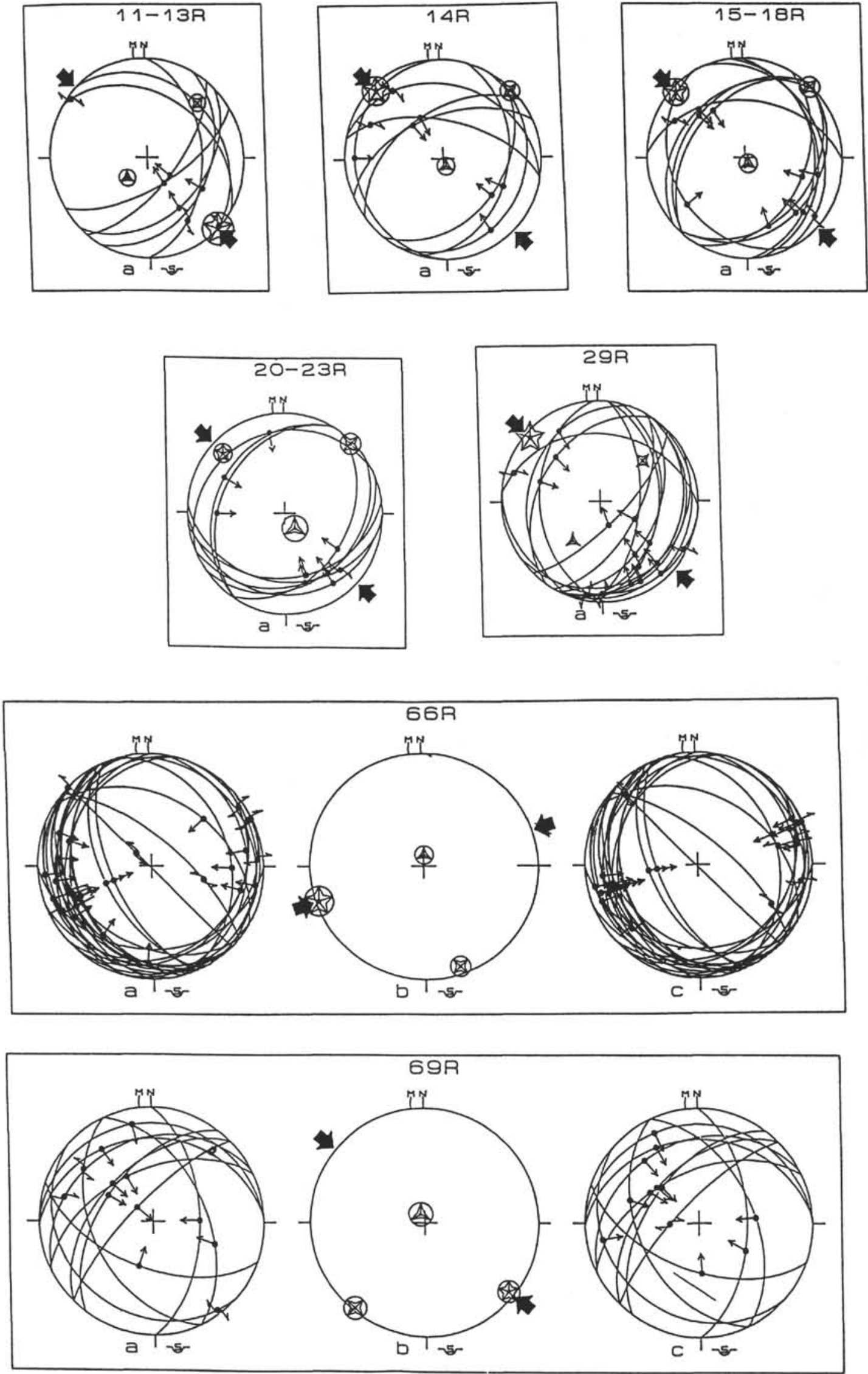

Figure 7. Stereonet showing inverted stress tensor for seven intervals at Site 808 (from Siegfried et al., this volume). Note the consistent trend of $\sigma_{1}$ in intervals represented by Cores 131-808C-11R to -29R (395-578 mbsf), as well as the apparent rotation in $\sigma_{1}$ in Core 131-808C-66R (924.8-934.5 mbsf). This latter interval corresponds to a zone of anomalous magnetic susceptibility (Fig. 4C) and velocity (Brückmann et al., this volume). Stress tensors from the décollement (Core 131-808C-69R; 953.8-963.4 mbsf), however, are consistent with most of the data from Site 808 and $\sigma_{1}$ trends nearly parallel to the plate convergence vector. 
A) PROGRESSIVE DEFORMATION

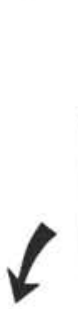

Stage d

rontal thrust and Shear localization
Stage c

Thin, closely spaced fault
zones
and
shear-enhanced
compaction

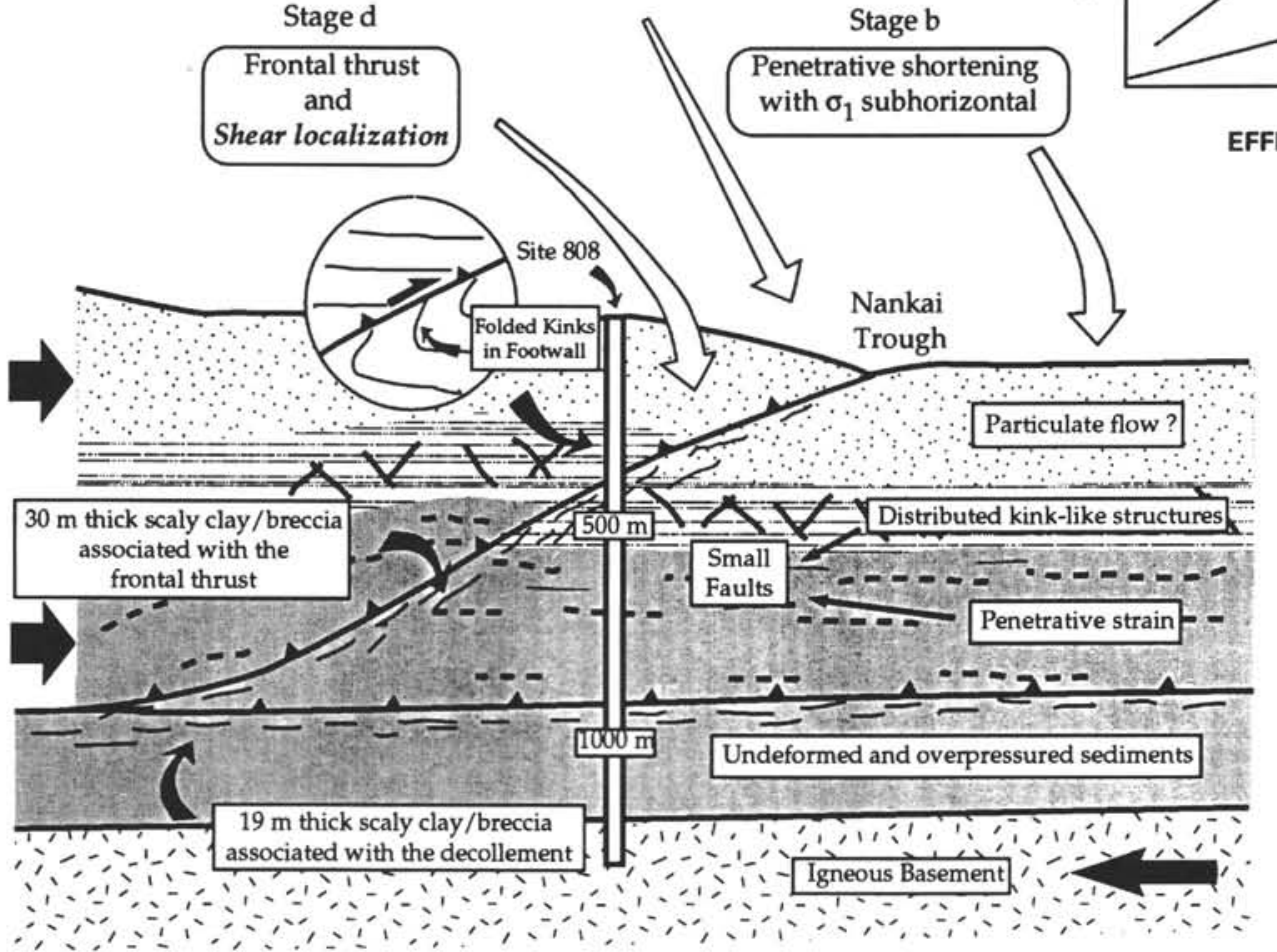

Trough

Turbidites

\section{Outer Marginal}

Trough Wedge

Shikoku Basin

Hemipelagic

Sediments

with ash

Shikoku Basin

Hemipelagic

Sediments

Subduction

Figure 8. Generalized cross section (A) of Site 808, and a deviatoric vs. mean stress diagram (B) that summarize the deformation history observed at this site. Evidence of the cross-cutting relations that define the progression from stage "b" to stage "d" are in Taira, Hill, Firth, et al, (1991), Byrne (this volume), Maltman et al. (this volume), and Owens (this volume). The short, crossing heavy lines represent kink-like structures. The dashed lines represent ash layers and the short squiggly lines show locations of scaly fabrics. Deviatoric stress vs. mean stress diagram (B) is modified from Wong et al. (1992) and the curve "a" to "d" is an interpretation based solely on the observations from Site 808 . 